\title{
LANGUAGE AND CULTURE IN THE DEAF COMMUNITY: A CASE STUDY IN A SOUTH AFRICAN SPECIAL SCHOOL
}

Marga Stander, Sol Plaatje University, South Africa

Guy McIlroy, University of the Witwatersrand, South Africa

An ethnographic case study on Deaf culture was done at the Thiboloha Special School in a rural area of the Free State province in South Africa. Two Deaf learners and three Deaf teaching assistants participated in this study. Although they were all part of the hearing Sotho culture, they were also full participants in the Deaf community. The study was done by means of video recordings, interviews, and questionnaires. The study reveals the diversity of the Deaf community with a vibrant and unique culture associated with this school, which gives them a sense of belonging. The analysis of the questionnaires, interviews, and recordings in this study shows how significant it is for the Deaf to be part of a Deaf community and culture, as well as part of a hearing community. It is important for them to be Deaf (with a capital ' $D$ ') and have a Deaf identity. It became evident in this study that Deaf people prefer to use Sign Language for communication purposes in the Deaf community. The study also shows the key role the school plays in introducing Deaf learners to Deaf culture and community, and South African Sign Language, which connects them to a wider Deaf and hearing community. The school became the participants' new community where they found their Deaf identity, their own language and culture. The school fulfilled its role to realise the importance and value of Deaf culture and community and succeeded in de-pathologising deafness. This study confirms the responsibility of and opportunity for schools to educate their Deaf learners about their culture and community.

Keywords: Deaf community, Deaf culture, Deaf Education, Deaf identity, human rights, South African Sign Language.

\section{INTRODUCTION}

In recognition of the World Federation of the Deaf's 1 (WFD) theme of 'strengthening human diversity', we present a case study that illustrates the diversity of the South African Deaf community. Although the participants in this study had been born into Sesotho hearing families, they used SASL to communicate and were full participants in the Deaf community.

The objectives of the study were to find out more about Deaf culture and language at Thiboloha Special School in a rural area of the Free State Province in South Africa, as well as what it means to be part of both a Deaf community and culture, and a hearing community. We also wanted to establish what role a school for the Deaf plays in introducing Deaf

\footnotetext{
${ }^{1}$ In this article, we use the upper-case 'D' (initiated by Woodward, 1972) to refer to the socio-cultural concept of deafness as a linguistic group, or community with a distinctive culture. For clarity, we use the lower case ' $d$ ' either as an adjective e.g. the deaf girl; deaf people; etc. or when we refer to the audiological condition (in accordance with convention in the field of Deaf Studies; Morgan, 2014: 255).
} 
learners to Deaf culture, community, and South African Sign Language (SASL). Lastly, we wanted to see how Deaf South Africans see themselves as members of society.

The research questions asked were whether being part of Thiboloha Special School as a Deaf learner or Deaf teaching assistant and using SASL as their own language connected participants to the wider Deaf community and what this meant to them. How important was being Deaf (with a capital ' $D$ ') and having a Deaf identity to them? How strong was their bond with the wider Deaf culture of South Africa regarding cultural diversity and what did it mean for them to be part of a minority (Deaf) community within a dominant hearing South African community?

Thiboloha Special School was chosen because of the lead author's proximity and access to this school as a specialist educational advisor and from her experiences of teaching at this school. The second author was born deaf, but became a SASL user after discovering his Deaf identity and is currently doing his $\mathrm{PhD}$ in Deaf Education.

\section{Deaf community}

Deaf people can be part of more than one community, language, and culture (see Heap, 2003), because they are members of different communities based on sharing, for example, location, experiences, goals, language, and identity (Storbeck \& Jurgens, 2007). The Deaf community has its own unique visual-manual language modality or sign language (Padden \& Humphries, 2005; Woodward, 1982: 17).

Most deaf children have hearing parents belonging to a different cultural group. Deaf children are enculturated into a Deaf culture through alternative means, such as at school (Heap, 2003; Ladd, 2003; Padden \& Humphries, 2005). Baker and Cokely (1980:55-56) present four possible avenues to membership into the Deaf community, namely, audiological (hearing loss); political (influence in the Deaf community); linguistic (understanding and use of sign language); and social (social functions of the Deaf community). The Deaf community is a community with a sense of belonging and becoming (Bauman, 2008; Morgan, 2014:258).

\section{Deaf culture}

Deaf culture can be defined in terms of Deafhood (Ladd, 2003: 3), which is not a 'static' medical condition like 'deafness'. Deafhood represents the struggle that Deaf people have to uphold themselves in a larger community of hearing and Deaf people (Ladd, 2003; Lewis, 2007; Morgan, 2014). Deaf culture, like many other cultures, is characterised by its social complexity, own beliefs, norms, values (Ladd, 2003), activities, shared oppression, diversity (Lane, Hoffmeister \& Bahan, 1996), history, customs, and technology, which are carried over to the next generation (Padden \& Humphries, 2006; Reagan, 2008).

Although Sign Language is an important element in Deaf culture, not all deaf people use it and instead use the oral method or Total Communication. Deaf children are seldom aware of what Deaf culture means when they first arrive at a school for the Deaf.

In most cases, a Deaf community is only one generation 'thick' because members of the community are the only deaf children in their families, but the culture itself is not 'thin'. The 'thickness' of Deaf culture is an important aspect to create a greater awareness through the richness of its community (Kusters, 2014). Some deaf children are not exposed to other deaf 
children at school (as individuals in mainstream classes), while in schools for the Deaf, children meet their deaf peers and are either socialised about Deaf culture formally in classes where there is Sign Language, or informally outside where Sign Language is not the language of learning and teaching (LOLT).

\section{The importance of Sign Language}

Deaf people regard Sign Language as the core part of their culture and community. Bauman and Murray (2009: 4) consider the uniqueness of American Deaf identity, community and languages, and state that the 'visual, kinesthetic nature [of sign language] is a source of diversity'.

Meir, Sandler, Padden and Aronoff (2010) claim that community sign languages emerge when signers from different backgrounds get together in one place, for example a school or club. Most use "home signs ${ }^{2}$ with their hearing families and have very little or no exposure to any language before coming to a school for the Deaf. They often associate themselves with schools for the Deaf, because that is where they learn and use sign language. For example, different signing communities in Adamorobe, Ghana, were formed through attending schools for the Deaf (Bahan, 1995; De Vos \& Zeshan, 2012; Erting, 1994; Kusters, 2014; Ladd, 2003; Meir et al., 2010; Nyst, 2007). This situation can be compared to the school in this study.

\section{Oppression and discrimination against the Deaf community}

According to Heap (2003: 126), the concept of 'community' has been used as a euphemism for 'race'. Furthermore, the Deaf 'live permanently in the [hearing] host society' and are 'often displaced, marginalized, discriminated against' (Heap, 2003: 127).

Historically, Deaf culture has been seen as inferior by the dominant hearing culture, resulting in oppression and discrimination (Woodward, 1982). Where this audist attitude towards deaf people and Sign Language persists or goes unchallenged, Deaf culture is not recognised. Picking up on this point, Lane (1992:31) argues that 'Deaf communities have been called colonised, ${ }^{3}$ because they have suffered oppression in all its forms and consequences'. Deaf people have had a difficult time overcoming this inferiority stereotyping (Woodward, 1982), also because deafness is viewed as a medical pathology. ${ }^{4}$

\footnotetext{
${ }^{2}$ Home sign language 'is a communication system created by an isolated deaf person and his/her hearing environment' (Nyst, 2007: 34). It often arises when a deaf child grows up within a non-signing hearing family and uses visual communication (both conventionalised gestures and creatively invented gestures) in a way that becomes conventionalised within that context (Goldin-Meadow, 2003)

${ }^{3}$ Lane (1992) compares the Deaf situation regarding sign language to that of Burundi when it was colonised by Belgium and French schools were established so that the people of Burundi could learn French and communicate with the wider government. Likewise, Deaf people were dictated to by hearing people and taught the language of the hearing majority.

${ }^{4}$ In the pathologic point of view, the focus is on the amount of hearing loss and how to correct it. This correction is done through using cochlear implants and hearing aids, and learning speech and lip-reading (Berke, 2017).
} 
Language oppression is often based on oral-manual controversy (the oral method is preferred to that of signing). Loughran (2013: 5) states that the dominant hearing majority often do not acknowledge Deaf people's cultural identity, perceiving sign language as a lesser form of communication and expecting the Deaf to adjust to the majority's way of life.

As a consequence, many Deaf people would rather communicate with a foreign Deaf person than with a local hearing person, because they see themselves as a colonised group (Loughran, 2013), a fact that was also mentioned by the participants in this study.

\section{THE SOUTH AFRICAN CONTEXT}

South Africa has 11 official languages, but SASL is not an officially recognised language. However, SASL is gradually being added in schools as a LOLT to the benefit of the Deaf learners, at schools for the Deaf.

\section{The Deaf community and culture in South Africa}

The Deaf community is unique in the sense that it consists of 'many micro-communities, each with their own sensitivities', frequently located in schools for the Deaf, although the Deaf community is often seen as one big community (Van Herreweghe \& Vermeerbergen, 2010: 131). Deaf people are divided among many languages, races, groups, cultures, and communities.

However, there are many misconceptions about the Deaf community. Many ignorant and uninformed hearing people often see the Deaf as disabled, handicapped, or impaired. In contrast, Deaf people do not see themselves in this way, as that they have lost something (like their hearing), but rather that they have gained something, i.e. 'Deaf Gain' (Bauman \& Murray, 2009). Van Herreweghe and Vermeerbergen (2010: 125) mention that Deaf identity is shaped by 'means of alienation from the hearing community and solidarity among the Deaf community (to a certain extent even across ethnic boundaries)' by virtue of the legacy of apartheid education that affected deaf children in different ways. Black deaf children with a poorly resourced education used sign language far more than the well-resourced white children in more privileged schools up to 1994. Interestingly, there has been a shift among white deaf children towards learning SASL, which was previously disparaged (Storbeck, Magongwa \& Parkin, 2009).

The situation at Thiboloha Special School in this study is typical of a local educational-based Deaf community where new members enter and leave the community on a regular basis. Some may choose to stay on at the school indefinitely to work as assistants or support staff, or for further training in skills development and to be part of a community that uses SASL (Aarons \& Akach, 2002).

Interestingly, when Deaf people embrace their Deaf culture, they remain part of a dominant (hearing) ${ }^{5}$ culture (Bauman, 2013; Meir et al., 2010) as multiculturals. Many Deaf people value their Deaf culture above their hearing culture. In other words, they are 'Deaf' first, and then they list their other identities, such as black or Afrikaans (Aarons \& Akach, 1998:25).

\footnotetext{
${ }^{5}$ The term 'hearing' is used to identify people who are members of the dominant community that values hearing and speech. The SASL sign for 'hearing' means to 'talk' and not to hear. For Deaf people, signing is the communicative equivalent of talking.
} 


\section{SASL and education in South Africa}

The Deaf community is often forced to make compromises in educational contexts (using unfamiliar languages as medium of instruction) as well as between SASL and the spoken language (where SASL is not recognised). Heap (2003) argues that SASL transcends South Africa's spoken languages, as well as geographical and historical divisions. However, the Deaf community is a linguistic minority (Aarons \& Akach, 2002; Morgan, 2008) and unfortunately, hearing teachers often do not perceive SASL as worthy of being an official language, a perception that seems to be changing with the roll-out of the SASL Curriculum and Assessment Policy Statement (CAPS). Hence, the Pan-South African Language Board (PanSALB) and DeafSA try to ensure the recognition of SASL and the language rights of the Deaf learners (DeafSA, n.d.; PanSALB, n.d.).

In South Africa, Deaf education has a unique history that is characterised by its struggle for recognition of Sign Language in education beyond its current concessionary recognition by the Department of Education as a LOLT. The teaching method in the first school for the Deaf (opened in 1974 in Cape Town) was manual and the spoken and written language was English. SASL as a medium of communication only returned to the classroom in 1988 with the establishment of the Noluthando School for the Deaf in Khayelitsha (Heap, 2003). Deaf learners transformed schools into living spaces where they learned SASL from each other (Morgan, 2014), and formed Deaf identities outside of the classroom on the playground and in residences (Van Herreweghe \& Vermeerbergen, 2010).

Thiboloha Special School in this study is an example of a community where SASL is used in close collaboration by deaf and hearing members competent in SASL (De Vos \& Zeshan, 2012). However, they might use sign-supported English (SSE) or Sesotho (Total Communication) with hearing people not competent in SASL. Hearing teachers with higher education training, but with no specific training in SASL or Deaf education, are often appointed rather than Deaf teachers who do not have any higher education qualifications, but who know SASL and are familiar with Deaf education. Consequently, classroom communication for Deaf learners has been a barrier to learning (Van Staden, Badenhorst \& Ridge, 2009).

\section{Oppression in the South African Deaf education context}

The concepts of ethnicity and discrimination in South Africa go hand in hand. For black Deaf people, discrimination came from two sides - colonial discrimination (before and during apartheid) and historical discrimination (the medical/pathological model) since 1880 (Heap, 2003; Reagan, 2011).

Apartheid had an impact on Deaf identities and communities (Van Staden et al., 2009), for example through 'segregated schools, inferior education under the Bantu education system for black deaf children and differential language policies for black and white children' (Morgan, 2014:256).

Heap (2003:72) mentions that, by 1904, Deaf learners were divided by spoken language (English or Dutch) and by method (Sign or oral). During the 1960s, only Total Communication was allowed in black schools (Morgan, 2014; Reagan, Penn \& Ogilvy et al., 2006). However, black Deaf people continued to sign and developed SASL, while their white deaf counterparts received funding for the oral approach. Most schools did not embrace 
bilingual education and were 'even in the post-apartheid era ... controlled by hearing principals, teachers and hostel parents' (Morgan, 2014:260). More recently, many white Deaf people have been discovering their Deaf identity and have become SASL users. They are claiming their place in the larger Deaf community. One of the authors of this article is a product of that scenario (Mcilroy, 2011).

It has taken the Deaf community 33 years to win the battle against linguistic oppression in schools (Morgan, 2014; Morgan, Glaser \& Magongwa, 2016), which eventually led to the acceptance of SASL by the Department of Education for use as a LOLT and as part of the SASL CAPS curriculum. To be admitted to university, students need at least two languages, which meant that in the past university entrance was not an option for Deaf students. However, with the inclusion of SASL as a language in Grade 12, Deaf learners are now able to study at university.

The struggle for the linguistic rights of SASL for Deaf people created a greater awareness of Deaf rights, consciousness, pride, unity, power, and identity (Morgan, 2008), which united them in their struggle against oppression and discrimination. The Deaf community has been divided across educational lines, but this has been addressed since 1994, when deaf learners of all races began to receive equal education (Storbeck et al., 2009).

\section{THE CASE STUDY}

An intrinsic case study was done at Thiboloha Special School, situated in a rural area in the Free State province of South Africa. The reason for this was to better understand the specific case and also because the case in itself was of interest (Stake, 1995).

The objective was to learn more about the Deaf culture and language at this school and how the Deaf see themselves as part of a wider Deaf (and hearing) community and culture. The contribution of the school in encouraging the use of SASL and participation in the Deaf community was specifically taken into account.

The following research questions were asked: whether the learners at this school were connected to the wider Deaf community/culture and the significance of being part of it; the importance of having a Deaf identity; and the significance of being Deaf.

\section{The school}

Learners as young as three years of age are admitted to the school. Most of the staff at the school are hearing, although Deaf staff occupy positions at the school more and more, such as teachers, teaching assistants, and interpreters, as well as in administration, cleaning, and caretaking. Because this is a boarding school, the majority of the Deaf learners and some of the staff members stay at the school, which allows them to participate in the local Deaf community (within a larger hearing community) at the school (Padden \& Humphries, 2005).

\section{The participants}

Two Deaf Grade 12 learners and three Deaf teaching assistants participated in this study. The names of the participants have been withheld and they were assigned different labels (see Table 1). These participants were not chosen because of any individual reason or characteristic. They were representatives of a much larger Deaf community and were chosen according to the manner in which they represented a certain group. An invitation was Per Linguam 2017 33(1):83-99 http://dx.doi.org/10.5785/33-1-688 
extended to the Deaf learners at the school and two Grade 12 learners, one male and one female (Learners 1 and 2), volunteered to partake in the study. The reason was to establish their awareness of Deaf culture and to establish what extent it had been acquired during their school years. Another reason for including them was because this class had been the first group that wrote the Grade 12 examination at this school and to see what impact it had made. Although they had SASL as a LOLT, it had not yet been included in the CAPS curriculum at the time the data were collected.

Teaching assistants and supporting staff at the school were also invited to partake in the study and two assistants, a young man and a young woman (Assistants 2 and 3) accepted the invitation. The reason was to perceive how they had already become part of adult Deaf culture and participated in the Deaf community. Although these assistants had SASL as a LOLT, they had not had the opportunity to write the final Grade 12 examination and had left the school after completing Grade 9.

Assistant 1 was invited because of her experience as a teaching assistant, as well as teaching her own SASL class. She had been at the school the longest and provided a more comprehensive perspective of her experiences in a Deaf community. She also played a prominent role in the Deaf community in and outside the school.

Both genders are represented in this study in order to get more objective perspectives on Deaf culture. The participants were all chosen because of their connection to the wider Deaf community and culture and because they all regarded having a Deaf identity as an essential feature of belonging to a Deaf community as the central criteria of participation in the study.

\section{METHODOLOGY}

In this ethnographic case study, a qualitative research method was followed, using interviews, video recordings, and transcripts as research instruments to collect the data. The interviewer (researcher) and interviewees used SASL during all conversations and interviews in the study. These were 'translated' from SASL to English using direct translation as well as a SASL gloss (a word-for-word transcription all written in capital letters in a spoken language, e.g. English). A content analysis approach was applied to analyse the data (Hsieh \& Shannon, 2005; Krippendorff, 2004) by coding the transcripts.

Informed consent was obtained from all the participants before the study was done. They were informed that their identities would be protected and the data would be anonymous. They agreed that the transcriptions of the videos could be used in the research and for publication. Ethical clearance was obtained for this research (Ethical Clearance number: UFS-HUM-2014-54).

\section{Research instruments}

Before the interviews were conducted in written English and SASL and recorded on video in SASL, a written copy of the interview sheet, in English (see Addendum), was given to each of the five participants and explained to them in SASL by the researcher for clarity.

The questions asked during the interviews and on the interview sheets addressed matters specifically related to Deaf Culture, namely, SASL, Deafhood, Deaf Clubs, communities, and connected issues (Morgan, 2014). After they had studied the questions and prepared their 
answers, an individual interview with each participant was first held by the researcher without the camera recording, to ensure that the researcher's signing was correct and understood by all. Open-ended questions were asked, for example, 'How did you feel growing up Deaf?' and, if the interviewee was not clear about the question, the researcher would explain or further related questions would be asked. All interviews were then recorded on video camera in SASL by the researcher with the help of one of the assistants.

Afterwards, the videos were played back to the participants to confirm their answers and agreement that it had been done in an acceptable manner. The researcher transcribed the recordings verbatim in SASL gloss and in written English. The transcriptions were typed by the researcher and showed to the interviewees to confirm their correctness.

All these interviews and discussions took place after school hours, over approximately a month, during learners' and assistants' free time. The Grade 12 classroom was used for this, since the researcher was also the class teacher for Grade 12. After all the participants agreed that the data were correct, the content analysis method (Hsieh \& Shannon, 2005; Krippendorff, 2004) was used to analyse the data.

\section{DATA ANALYSIS}

The data were analysed by reading each transcript and highlighting the responses to a specific question, in order to develop an axial coding process (identifying relationships among the codes), using the words from the answers. Once these codes had been identified, they were organised into main and sub-categories to establish a general response or opinion among the participants.

\section{RESULTS AND DISCUSSION}

The main categories and sub-categories were organised as follows:

- Biographical data: age; gender; birth; family; home language (Table 1).

- The role of the school in Deaf Culture and SASL: first school and age; SASL; English; Deaf culture (Table 2).

- The importance of Deaf community and culture: Deaf clubs; church; community; sport (Table 3).

- Wider Deaf and hearing communities: Deaf and hearing cultures (differences); Deaf from foreign countries (Table 4).

- Self-perception: how participants saw themselves as Deaf in the society.

\section{Biographical data}

The biographical data of the participants can be seen in Table 1.

Table 1: Biographical data of participants

\begin{tabular}{|l|l|l|l|l|l|}
\hline Participant & Age & Gender & Born & Family & Home language \\
\hline Learner1 & 20 & Female & Deaf & Hearing & Sesotho \\
\hline Learner2 & 19 & Male & Hearing & Hearing & Sesotho \\
\hline Assistant1 & 40 & Female & Hearing & Hearing & Sesotho \\
\hline Assistant2 & 24 & Male & Hearing & Hearing & Sesotho \\
\hline Assistant3 & 24 & Female & Deaf & Hearing & Sesotho \\
\hline
\end{tabular}


All participating learners had been born in the Sotho hearing culture, but became active members of the Deaf community. However, Assistant1 had married a deaf spouse and her brother had a deaf daughter of whom she was very proud, because this allowed her to continue to practice SASL and Deaf culture at home (cf. Meir et al., 2010; Morgan, 2014).

\section{The role of the school in Deaf culture and SASL}

The responses about the role of the school regarding the age at which the participants started school, where they learned SASL and Deaf culture, and what they used SASL and English for, are captured in Table 2.

Table 2: The role of Thiboloha Special School (TSS)

\begin{tabular}{|l|l|l|l|l|l|}
\hline Participant & $\begin{array}{l}\text { First school } \\
\text { and age }\end{array}$ & $\begin{array}{l}\text { Learned SASL } \\
\text { at/from }\end{array}$ & Use SASL for & Use English for & $\begin{array}{l}\text { Learned Deaf } \\
\text { culture at/from }\end{array}$ \\
\hline Learner1 & TSS, age 3 & $\begin{array}{l}\text { TSS, e.g. } \\
\text { signing, hand } \\
\text { shapes, } \\
\text { movement, } \\
\text { fingerspelling }\end{array}$ & $\begin{array}{l}\text { Communicating } \\
\text { with Deaf and } \\
\text { hearing }\end{array}$ & $\begin{array}{l}\text { School and } \\
\text { learning/ writing }\end{array}$ & $\begin{array}{l}\text { TSS, e.g. use for } \\
\text { cell phone, tapping } \\
\text { on shoulder, greet } \\
\text { other Deaf people }\end{array}$ \\
\hline Learner 2 & TSS, age 4 & $\begin{array}{l}\text { TSS - from } \\
\text { teachers/ } \\
\text { wider Deaf } \\
\text { community }\end{array}$ & $\begin{array}{l}\text { Learning/ } \\
\text { communicating } \\
\text { with other Deaf/ } \\
\text { teachers }\end{array}$ & $\begin{array}{l}\text { Learning/ } \\
\text { writing/ support } \\
\text { SASL }\end{array}$ & $\begin{array}{l}\text { TSS and wider Deaf } \\
\text { community }\end{array}$ \\
\hline Assistant1 & TSS, age 4 & $\begin{array}{l}\text { TSS - from } \\
\text { teachers/ by } \\
\text { copying other } \\
\text { deaf learners }\end{array}$ & $\begin{array}{l}\text { Teaching/ } \\
\text { communicating }\end{array}$ & $\begin{array}{l}\text { Teaching/ } \\
\text { writing/ } \\
\text { communicating } \\
\text { with hearing }\end{array}$ & $\begin{array}{l}\text { TSS and Deaf } \\
\text { community }\end{array}$ \\
\hline Assistant 2 & $\begin{array}{l}\text { Hearing } \\
\text { school, age 6 }\end{array}$ & $\begin{array}{l}\text { TSS - from } \\
\text { teachers/ peers }\end{array}$ & $\begin{array}{l}\text { Teaching/ } \\
\text { communicating }\end{array}$ & $\begin{array}{l}\text { Teaching/ } \\
\text { writing }\end{array}$ & $\begin{array}{l}\text { Other Deaf people/ } \\
\text { community/ not a } \\
\text { conscious process }\end{array}$ \\
\hline Assistant 3 & TSS, age 3 & $\begin{array}{l}\text { TSS - from } \\
\text { teachers/ class } \\
\text { assistants/ older } \\
\text { deaf learners }\end{array}$ & $\begin{array}{l}\text { Teaching/ } \\
\text { communicating }\end{array}$ & $\begin{array}{l}\text { Teaching/ } \\
\text { writing/ } \\
\text { communicating } \\
\text { with hearing }\end{array}$ & TSS \\
\hline
\end{tabular}

Although all of the participants were from hearing Sesotho families, none of them communicated in written or spoken Sesotho at school (none of them had Deaf parents, which is a typical demographic reality). Instead, they used English for written and educational purposes and SASL for communication purposes in the Deaf community. The school forms an important aspect of the Deaf community. For the participants, it became their new community away from home, where they met other Deaf people and made new Deaf friends. They learned about their Deaf identity, SASL, and Deaf culture at Thiboloha Special School for the first time. These participants all experienced a 'sense of belonging' and being in a comfortable Deaf space (Morgan, 2014) when they used SASL.

The importance of the role the school played in the lives of these participants is confirmed by the response by Assistant1 (direct translation from SASL to English): 'Me feel alone...why, all friends mine hearing...me out alone...then meet Deaf...me happy. Learned SASL and culture... school here. Also background, I copied [other Deaf].'

It was also observed at the school that some of the learners could lip read to a certain extent when hearing speakers tried to use Sesotho-supported SASL with them. Those learners who 
had become deaf later or who were hard of hearing, used a combination of SASL and Sesotho words when they communicated with hearing Sesotho speakers.

\section{The importance of a Deaf community and culture}

The responses by the participants regarding belonging to a Deaf club and the Deaf church, sport, and the importance of Deaf community are captured in Table 3.

Table 3: Deaf community and culture

\begin{tabular}{|l|l|l|l|l|}
\hline Participant & $\begin{array}{l}\text { Belong to Deaf Club/ } \\
\text { where }\end{array}$ & Deaf church & Sport & $\begin{array}{l}\text { Importance of Deaf } \\
\text { community }\end{array}$ \\
\hline Learner1 & Not yet & $\begin{array}{l}\text { Meet socially at } \\
\text { church }\end{array}$ & $\begin{array}{l}\text { Bowls, netball, } \\
\text { table tennis, and } \\
\text { dancing/ } \\
\text { competitions }\end{array}$ & $\begin{array}{l}\text { Socialisation/ } \\
\text { friendships/ having } \\
\text { fun/ discussions with } \\
\text { friends }\end{array}$ \\
\hline Learner2 & $\begin{array}{l}\text { Not at school, but } \\
\text { outside school }\end{array}$ & Member & No & $\begin{array}{l}\text { Deaf friend outside } \\
\text { school }\end{array}$ \\
\hline Assistant1 & $\begin{array}{l}\text { At school and outside/ } \\
\text { women's club (very } \\
\text { important) }\end{array}$ & $\begin{array}{l}\text { Leading figure in } \\
\text { church/ stood in } \\
\text { when the pastor was } \\
\text { away }\end{array}$ & $\begin{array}{l}\text { When younger } \\
\text { (netball, bowls) }\end{array}$ & $\begin{array}{l}\text { Socialisation/ } \\
\text { friendships }\end{array}$ \\
\hline Assistant2 & At school and outside & Member & $\begin{array}{l}\text { Soccer/ } \\
\text { competitions }\end{array}$ & $\begin{array}{l}\text { Friendships in and } \\
\text { outside school }\end{array}$ \\
\hline Assistant3 & At school and outside & Member & $\begin{array}{l}\text { Netball/ } \\
\text { competitions }\end{array}$ & $\begin{array}{l}\text { Friendships in and } \\
\text { outside school }\end{array}$ \\
\hline
\end{tabular}

The Deaf Club was an informal club and attendance was not recorded; however, it seemed that they met regularly. As members of this club, their 'Deafhood' was being embraced (cf. Morgan, 2014). Being part of the Deaf community or culture means being part of a Deaf club. Assistant1 explained why it was so important for them to belong to a Deaf women's club and to share their experiences with other Deaf women, for example, how difficult it is for Deaf people to bring up a child in a hearing community. Assistant1 was one of the founder members of this club, which had been founded approximately eight years prior to this study. They had about three formal meetings per year, although they met more often on an informal basis. There was no entry age or age restriction for belonging to the club; the only precondition was that one had to be finished with school. Nearly all Deaf females who had completed school, as well as the pastor's wife (also Deaf), belonged to this club. The club focused on issues that were important to Deaf women, such as marriage, relationships, children, skills training, health, religion, education, SASL, and Deaf rights. When they organised a social event, it involved mostly Deaf people, interpreters, and hearing people who used or understood SASL.

The Deaf Church, founded in 2010 and situated on the school grounds, filled a gap in the lives of the Deaf. It made them feel part of a Deaf community. This was confirmed by Learner1, who said, 'I suffered, was poor, but now have...last year, 2010, new...Deaf Pastor...he build church, have...blessing from God, for sick, poor, [people with] worries...'

Participation in sport was very important to all the participants. It assured that they were part of the wider community, whether Deaf or hearing. They had regular sport competitions with other schools and provinces (Deaf and hearing). Because there were only two schools for the Deaf in the Free State province, they had competitions with mostly hearing schools. 
The Deaf at this school cherished the school as a space where they could 'function socially' in SASL without 'communication barriers' and saw it as a space where they belonged (cf. Heap, 2003; Morgan, 2014:261). Therefore, it was extremely important for them to be part of a community; even more important was their community's acceptance of them as Deaf. They all mentioned that, without a 'sense of belonging', they felt rejected and depressed. Morgan (2014) mentions that Deafhood and a sense of belonging emerged as a result of oppression by the hearing world.

\section{The wider community (Deaf and hearing)}

The responses by the participants regarding Deaf people from foreign countries and differences between Deaf and hearing cultures are captured in Table 4.

Table 4: Deaf and hearing community

\begin{tabular}{|l|l|l|}
\hline Participant & Deaf from foreign countries & Deaf and hearing culture: differences \\
\hline Learner1 & $\begin{array}{l}\text { Understood foreign Deaf better because } \\
\text { of sign language/ could easily use cell } \\
\text { phones and other media to communicate }\end{array}$ & $\begin{array}{l}\text { Did not understand hearing from South Africa/ } \\
\text { misunderstandings/ different hearing culture, } \\
\text { e.g. the use of cell phones is different/ different } \\
\text { writing culture }\end{array}$ \\
\hline Learner2 & $\begin{array}{l}\text { Understood foreign Deaf because of } \\
\text { facial expressions }\end{array}$ & $\begin{array}{l}\text { Understood hearing people through writing and } \\
\text { interpreters }\end{array}$ \\
\hline Assistant1 & $\begin{array}{l}\text { Understood foreign Deaf through facial } \\
\text { expression/ body language/ movement }\end{array}$ & $\begin{array}{l}\text { Did not understand hearing/ misunderstandings } \\
\text { because of different cultures }\end{array}$ \\
\hline Assistant2 & Sign language easier for communication & $\begin{array}{l}\text { Difficult to communicate with hearing because } \\
\text { of different culture }\end{array}$ \\
\hline Assistant3 & Did not understand foreign Deaf well & Understood hearing when using SASL \\
\hline
\end{tabular}

When the Deaf meet Deaf people from other countries, it is important for them that they can easily connect with them. This was confirmed in the responses given by the participants. Four of them said they had much more in common with Deaf people in general than with hearing people; they could read their facial expressions, and many sign languages have similar signs, body language, and movement. This correlates with Bauman and Murray's (2009) observation that Deaf people who meet Deaf people from foreign countries can almost instantly communicate with each other, using improvised and international signs; in addition, there are no formal language boundaries as is the case for hearing people (Heap, 2003).

Assistant 1 explained the different modes of communication and affirmed that the Deaf would like to follow their own culture and use SASL with their hearing children. However, they tended to respectfully follow the culture of their hearing Sesotho families where family traditions were very important and grandparents were very involved with the upbringing of children. (cf. Clark, 2003). She said, 'Culture also different, how? Communicate differently. Culture [of] hearing people and deaf people different. Example, deaf family culture, example when baby [is] born. But Deaf bring baby to hearing family...teach their culture...how we do about baby.'

Learner1 explained that hearing people follow a 'hearing structure' when they write, which is often difficult for the Deaf to understand '...when people in community talk, speak, listen and write English...isiZulu, isiVenda, isiXhosa, Afrikaans...they focus on hearing structure when they write, they have English structure... me, I not do that.' This implies that Deaf culture goes much deeper than the obvious, e.g. language, beliefs, norms, values, and history, and that further investigation into the matter of writing as part of culture is necessary.

Per Linguam 2017 33(1):83-99

http://dx.doi.org/10.5785/33-1-688 


\section{Self-perception}

When the participants were asked to describe themselves, it was clear from their answers that they were very much aware of their rights, responsibilities, and relationships. This is confirmed in the response given by Learner2: 'For me, is about Deaf. I want encourage Deaf clubs have contact with [other] people, like Deaf clubs. Person must encourage change, go outside provinces'.

They also enjoyed working with smaller children and other Deaf people, helped others, influenced them positively, and encouraged them to do better. This is confirmed in the following responses by Learner1 and Assistant1:

Learner1: 'Me Grade 12. Favourite [subject] drawing, because of person face. I love my friends, I love small children, because they suffer, I teach them, I [want to] influence them [to] respect teacher, have good communication. I love my family, have many problems. I always pray...my family love me, I love [them], they all fine.'

Assistant1: 'I like help, teach children, in assembly, girls hostel. Teach about Jesus from Bible. I counsel them about future education, maybe they lose education. I motivate them.'

The Deaf are proud about their Deafness and care about their families and small Deaf children in general. Although the participants loved their families very much, they did not often succeed in their communication with them, despite the various communication strategies mentioned earlier. Most parents do not know enough SASL to use it to communicate fluently with their deaf child. What does this say about their identity? They are proud of themselves as Deaf people, despite the communication barriers at home and, at times, at school.

This caring for and motivating other Deaf people might indicate a concern for the preservation of their Deaf culture and community. Because Deaf cultures are minority cultures, they might easily 'disappear' into a vast hearing culture.

\section{CONCLUSION}

Depriving deaf people of their rights to their own community and culture means that deaf people in South Africa are alienated and may not have the sense of belonging that was so evident among members of a Deaf community at a school in this study. For them, two interconnected things stood out. Firstly, having their own language, i.e. SASL, was extremely important, indeed, central, for their well-being and everyday existence. Secondly, without a Deaf community and a Deaf culture in which they could fully exist, they would be oppressed, depressed, and isolated deaf persons.

The research question, whether being part of Thiboloha Special School and using SASL connected them to the wider Deaf community, was answered positively by the participants. They illustrated that this was important to them, because it shaped their Deaf identity and 'sense of belonging'. The second research question was also confirmed by the participants that being Deaf and having a Deaf identity was very important to them and made them feel proud of themselves as deaf persons. This is further illustrated by Bauman and Murray (2009:9), who mention that the birth of a deaf baby can cause anxiety, but that the 'new frame, the frame of Deaf Gain, sees the baby not as a problem but as an asset'. Like 
Assistant1 aptly said, (in SASL gloss - a word-for-word transcription from SASL in capital letters in English): 'FAMILY MINE ALL HEARING BUT LUCKY SECOND MY BROTHER HAVE DEAF CHILD SHE GIRL' [My family are all hearing, but luckily my second brother has a deaf child, a girl]. There are many reasons for this Deaf pride sentiment, such as: they can communicate with their child; their child will be part of their culture; it brings the family closer together; and they can identify and support the child with the challenges he or she has to face. The birth of a Deaf child means that their community, culture and SASL are growing and developing.

The research question on how strong their bond with the wider Deaf culture of South Africa was regarding cultural diversity can be answered by saying that, as members of an established culture, this Deaf community served to strengthen their cultural diversity and it gives them a sense of inclusivity. To answer the last question, it can be confirmed that this community had strong self-esteem as individuals to play their part in a minority community (with a Deaf identity) within a dominant community (hearing) with all the responsibilities and expectations of active citizens of our country.

One of the objectives of the study was to find out what role this school played in introducing Deaf learners to Deaf culture, and it can be said that this school realised the importance of the depth and value of Deaf culture and community and succeeded in de-pathologising deafness. The findings in this study reinforce the responsibility and opportunity of schools to educate their deaf learners about Deaf culture and Deaf community into becoming healthy and proud Deaf adults. It would also help the Deaf community if schools hired more Deaf assistants and qualified Deaf teachers in order to enlarge the connection with Deaf people from other schools for the Deaf and with hearing people.

The results endorse the fact that there are commonalities among Deaf communities, regardless of their different backgrounds, where they grew up and which region they had come from before they came to this school.

\section{ACKNOWLEDGEMENTS}

We would like to thank Thiboloha Special School for granting us permission to conduct this study. We would especially like to thank the two Deaf learners and three Deaf assistants from the school for their participation in this study.

\section{REFERENCES}

AARONS, D \& P AKACH. 1998. South African sign language: One language or many? A sociolinguistic question. Stellenbosch Papers in Linguistics, 31:1-28. DOI: https://doi.org/10.1017/CBO9780511486692.007

AARONS, D \& P AKACH. 2002. South African sign language: One language or many? In Mesthrie, R (Ed.), Language in South Africa. Cambridge: Cambridge University Press. 127-147.

AARONS, D \& L REYNOLDS. 2003. South African Sign Language: Changing policies and practice. In Monoghan, L, C Schmaling, K Nakamura \& GH Turner (Eds), Many ways to be Deaf: International variation in Deaf communities. Washington, DC: Gallaudet University Press. 194-210. 
AKACH, P. 2010. Application of South African Sign Language (SASL) in a bilingualbicultural approach in education of the Deaf. PhD thesis, University of Free State, Bloemfontein.

AKACH, P, E DEMEY, E MATABANE, M VAN HERREWEGHE \& M VERMEERBERGEN. 2009. What is South African Sign Language? What is the South African Deaf community? In Brock-Utne, B \& I Skattum (Eds), Languages and education in Africa. A comparative and transdisciplinary analysis. Oxford: Symposium Books. 125-144.

BAHAN, B \& JCP NASH. 1996. Visions of the past - visions of the future. In Conference proceedings DEAF STUDIES IV. Washington, DC: Gallaudet University. 1-26.

BAKER, C \& D COKELY. 1980. American Sign Language: A teacher's resource text on grammar and culture. Silver Spring, MD: TJ Publishers.

BAKER, C \& C PADDEN. 1978. American Sign Language: A look at its structure, history, and community. Silver Spring, MD: Linstok Press.

BAUMAN, HD. 2008. Introduction: Listening to Deaf studies. In Bauman, HL (Ed.), Open your eyes: Deaf studies talking. Minneapolis, MN: University of Minnesota Press. 132.

BAUMAN, HD \& JM MURRAY. 2009. Reframing: From hearing loss to Deaf gain. Deaf Studies Digital Journal, (1). Available from http://dsdj.gallaudet.edu/assets/section/section2/entry19/DSDJ_entry19.pdf [Accessed: 2 October 2016].

BAUMAN, N. 2013. New to hearing loss? Here's the help you need! Available from http://hearinglosshelp.com/blog/new-to-hearing-loss-heres-the-help-you-need/ [Accessed: 2 June 2014].

BERKE, J. 2017. Pathological vs. cultural point of view on deafness. Available from: http://deafness.about.com/od/deafculture/a/pathcultural.htm [Accessed: 13 June 2017].

CLARK, K. 2003. Children of Deaf adults: Communication and parenting issues in families with deaf parents and hearing children. Available from http://www.lifeprint.com/as1101/pages-layout/coda.htm [Accessed: 12 January 2015].

DE VOS, C \& U ZESHAN. 2012. Introduction: Demographic, sociocultural, and linguistic variation across rural signing communities. In Zeshan, U \& C de Vos (Eds), Sign languages in village communities: Anthropological and linguistic insights. Berlin: Mouton De Gruyter. 2-23.

DEAFSA. n.d. DeafSA website. Available from http://www.deafsa.co.za/ [Accessed: 18 January 2016]

ERTING, C. 1994. The Deaf Way: Perspectives from the international conference on Deaf culture. Washington, DC: Gallaudet University Press.

FERRANTE, J. 2013. Sociology: A global perspective (8th ed.; international ed.). Wadsworth, $\mathrm{OH}$ : Cengage Learning.

GOLDIN-MEADOW, S. 2003. The resilience of language: What gesture creation in deaf children can tell us about how all children learn language. New York, NY: Psychology Press.

HEAP, M. 2003. Crossing social boundaries and dispersing social identity: Tracing deaf networks from Cape Town. PhD dissertation, University of Stellenbosch.

HSIEH H \& SE SHANNON. 2005. Three approaches to qualitative content analysis. Qualitative Health Research,15(9):1277-1288. DOI: https://doi.org/10.1177/1049732305276687

JANSEN, J. 2013. Wrest power from English tyranny. Mail and Guardian, 4 October. 
JAY, M. 2011. Deaf culture. Available from: https://www.start-american-signlanguage.com/deaf-culture.html [Accessed: 5 October 2016].

KRIPPENDORFF, K. 2004. Content analysis: An introduction to its methodology. London: Sage.

KUSTERS, A. 2014. Language ideologies in the shared signing community of Adamorobe. Language in Society, 43(2):139-158. DOI: https://doi.org/10.1017/S0047404514000013

LADD, P. 2003. Understanding deaf culture: In search of deafhood. Clevedon: Multilingual Matters.

LANE, H. 1992. The mask of benevolence: Disabling the Deaf community. New York: Knopf.

LANE, H, R HOFFMEISTER \& B BAHAN. 1996. A journey into the Deaf-World. San Diego, CA: Dawn Sign.

LEONARD, A, D DUREN \& J REIMAN. 2003. Considerations for mediating with people who are culturally deaf. Available from: http://www.mediate.com/articles/cadre6.cfm [Accessed: 15 October 2016].

LEWIS, H. 2007. Deaf liberation theory. London: Routledge.

LOUGHRAN, S. 2013. Cultural identity, deafness and sign language: A postcolonial approach. $L U X, 2(1): 1-8$. DOI: https://doi.org/10.5642/lux.201301.19

MCILROY, G. 2011, Development of Deaf identity. Journal of Deaf Studies and Deaf Education, 16(4):494-511. DOI: https://doi.org/10.1093/deafed/enr017

MEIR, I, W SANDLER, C PADDEN \& M ARONOFF. 2010. Emerging sign languages. In Marschark, M \& PE Spencer (Eds), Oxford handbook of deaf studies, language, and education (Vol. 2). Oxford: Oxford University Press. 267-280.

MORGAN, RZ, M GLASER \& L MAGONGWA. 2016. Constructing and rolling out the new South African Sign Language (SASL) curriculum - Reflexive critique. Per Linguam, 32(2):15-29. DOI: https://doi.org/10.5785/32-2-648

MORGAN, RZ. 2008. Deaf me normal. Deaf South Africans tell their life stories. Pretoria: Unisa Press.

MORGAN, RZ. 2014. A narrative analysis of Deafhood in South Africa. Southern African Linguistics and Applied Language Studies, 32(3):255-268. DOI: https://doi.org/10.2989/16073614.2013.837615

NYST, V. 2007. A descriptive analysis of Adamorobe Sign Language (Ghana). Utrecht: LOT.

PADDEN, C. 1980. The deaf community and the culture of deaf people. In Baker, C \& R Battison (Eds), Sign language and the deaf community. Silver Spring, MD: National Association of the Deaf.

PADDEN, C, \& T HUMPHRIES. 2005. Inside Deaf culture. London: Harvard University Press.

PAN-SOUTH AFRICAN LANGUAGE BOARD [PANSALB]. n.d. PanSALB website. Available from http://www.pansalb.org.za/ [Accessed: 18 January 2016].

REAGAN, T, C PENN \& D OGILVY. 2006. From policy to practice: Sign language developments in post-apartheid South Africa. Language Policy, 5(2): 187-208. DOI: https://doi.org/10.1007/s10993-006-9002-y

REAGAN, T. 2008. South African Sign Language and language-in-education policy in South Africa. Stellenbosch Papers in Linguistics, 38:165-190. DOI: https://doi.org/10.5774/38$\underline{0-28}$

REAGAN, T. 2011. Ideological barriers to American Sign Language: Unpacking linguistic resistance. Sign Language Studies, 11, 606-636. DOI: https://doi.org/10.1353/sls.2011.0006

Per Linguam 2017 33(1):83-99

http://dx.doi.org/10.5785/33-1-688 
STAKE, RE. 1995. The art of case study research. Thousand Oaks, CA: Sage.

STORBECK, C \& J JURGENS. 2007. Sign language for education: Theory and practice 1. Johannesburg: University of the Witwatersrand.

STORBECK, C, L MAGONGWA \& I PARKIN. 2009. Education of the deaf in South Africa. In Moores, DF \& MS Miller (Eds), Deaf people around the world: Educational and social perspectives. Washington, DC: Gallaudet University Press. 133-144.

STORBECK, C, L MAGONGWA \& I PARKIN. 2012. Education of the deaf in South Africa. Available from http://www.deafsa.co.za/documents/ArticleonDeaf Education.pdf [Accessed: 2 February 2015]

THORNTON, R \& M RAMPHELE. 1988. The quest for community. In Boonzaier, E \& J Sharp (Eds), South African keywords: The uses and abuses of political concepts. Cape Town: David Phillips. 1-16.

VAN HERREWEGHE, M \& M VERMEERBERGEN. 2010. Deaf perspectives on communicative practices in South Africa: institutional language policies in educational settings. Text \& Talk, 30(2)2:125-144. DOI: https://doi.org/10.1515/TEXT.2010.007

VAN STADEN, A, G BADENHORST \& E RIDGE. 2009. The benefits of sign language for deaf learners with language challenges. Per Linguam, 25(1):44-60.

WOODWARD, J. 1972. Implications for sign language study among the Deaf. Sign Language Studies, 1(1):1-7.

WOODWARD, J. 1982. How you gonna get to heaven if you can't talk with Jesus: On depathologizing deafness. Silver Spring, Maryland: TJ Publishers.

\section{BIOGRAPHICAL NOTES}

Marga Stander currently teaches English, Communication and Sign Language at the Sol Plaatje University in Kimberley. She previously taught Afrikaans Linguistics at the Qwaqwa Campus of the Universities of the North and Free State and coordinated the Unit for Language Development. She also taught at a Special School in Qwaqwa.

Guy Mcilroy is a bilingual deaf lecturer in Deaf Education at the Centre for Deaf Studies at WITS. Guy is doing a PhD on teachers' transformation to sign bilingualism. His interests are Deaf pedagogy and sign bilingualism, Deaf identities, Deaf-led research, Deaf epistemology and Deaf narratives. 


\section{ADDENDUM}

\section{INTERVIEW SHEET}

The following questions were asked during the interview; not necessarily in the same order for all of the interviewees.

\begin{tabular}{|c|c|c|}
\hline & Question & Answer \\
\hline 1 & What is your name? & \\
\hline 2 & How old are you? & \\
\hline 3 & $\begin{array}{l}\text { What are your main languages and what additional languages do } \\
\text { you speak/use? }\end{array}$ & \\
\hline 4 & Do you have a hearing or a Deaf family? & \\
\hline 5 & $\begin{array}{l}\text { Are you in/did you go to a hearing school or a school for the Deaf? } \\
\text { If so, where? }\end{array}$ & \\
\hline 6 & How did you feel growing up Deaf? & \\
\hline 7 & $\begin{array}{l}\text { Where did you learn about Deafness, Sign Language and Deaf } \\
\text { Culture? }\end{array}$ & \\
\hline 8 & Do you belong to a Deaf Club? & \\
\hline 9 & Which communities do you belong to? & \\
\hline 7 & Do you belong to a sports community? & \\
\hline 8 & $\begin{array}{l}\text { In your opinion, are Deaf and hearing people different? If so, in } \\
\text { what way? }\end{array}$ & \\
\hline 9 & $\begin{array}{l}\text { Do you relate better to South African hearing people, or to foreign } \\
\text { Deaf people? What is the reason for your answer? }\end{array}$ & \\
\hline 10 & How would you describe yourself? & \\
\hline
\end{tabular}

